\title{
A Filosofia Trabalhista da Revolução de Março
}

Ministro JARBAS PASSARINHO

SUMÁRIO: Introdução - Fundamentos da Política Trabalhista Revolucionária - Definição Doutrinária - Visão do Trabalho - 0 Trabalho em face da propriedade: A propriedade privada. A propriedade coletiva - A Remuneração do Trabalho - Salário-mínimo Os Sindicatos - O papel da Emprêsa.

\section{INTRODUÇÃO}

No seu longo e tortuoso itinerário, desde as origens marcadas pela influência fascista da "Carta del Lavoro" até a tentativa da implantação do arremêdo "Justicialista", o trabalhismo brasileiro, em verdade, não teve uma definição ideológica. Exceto pela atuação dos ativistas marxistas, que sempre Ihe disputaram o poder, para usar os sindicatos como instrumentos de sua luta de classes, o movimento trabalhista brasileiro viveu apenas o estágio da política de clientela. Os governos pseudotrabalhistas, ou ávidos de popularidade, calculadamente distribuiam favores, individuais ou grupais, como forma de se assegurarem o apoio das cúpulas corrompidas e corruptoras e, através delas, obterem a simpatia da massa operária.

Os favores, pagava-os a Nação e, em última análise, pagavam-nos os próprios trabalhadores. Em 1964 havíamos chegado ao clímax dos efeitos perniciosos dessa política de clientela trabalhista. A previdência social, salvo pouquíssimas exceções, desastradamente administrada, era a imagem viva de institutos ineficientes, do empreguismo nepotista e de escândalos de tôda ordem.

A fiscalização do trabalho era inexistente e suspeita no mais alto grau. Basta notar que para garantir o trabalhador, elo mais fraco da cadeia de produção, havia 5 inspetores de trabaTho para todo Goiás, 35 para Pernambuco, 25 para Rio Grande do Sul, 30 para Minas Gerais! Na Guanabara, cuja importância Ao ser divulgado êste trabalho, nos primeiros dias de novembro de 1969, o
Ministro Júlio Barata já havia substituído na pasta do Trabalho e Previdência
Social

e Cultura. 
na economia brasileira é indiscutível, não havia mais que 270 inspetores e 300 em São Paulo.

Havia, portanto, apenas uma farsa, quanto à garantia do trabalhador contra os excessos e os abusos do capital. Isso para não falar no total desaparelhamento da fiscalização específica de higiene e segurança do trabalho.

A política de salários media-se pela improvisação e pelo prestígio de cada grupo reivindicador. Dentro da anarquia salarial produzida pela concessão demagógica de aumentos nominais desordenados, produzia-se a injustiça dos reajustamentos substancialmente diferentes. Assim é que, em 1963, para um mesmo local de trabalho, mas para categorias profissionais diversas, houve aumentos que variavam entre $105 \%$ e $27 \%$ !

Claro que isso decorria da conveniência de o Estado favorecer grupos de pressão sindicais, na medida que êsses grupos eram vitais à sua imagem de govêrno trabalhista, o que o levava inclusive ao desempenho do papel de patrocinador de greves.

Como conseqüência, a indústria e o comércio não absorviam a mão-de-obra deslocada dos campos. A inflação, autoalimentada pelos deficits descontrolados do Tesouro e pelos aumentos demagógicos dos salários das categorias mais agressivas de trabalhadores, acumulava mais de $23 \%$ só no primeiro trimestre de 1964 , ameaçando chegar a mais de $140 \%$ naquele ano, tiranizando a vida de todos os que dependiam de salários ou vencimentos fixos. Os setores fundamentais transportes, energia, comunicações, educação, saúde, saneamento - padeciam de enorme atraso e desorganização. $O$ crescimento do produto nacional bruto baixara tanto que o produto real por habitante, em 1963, chegou a ser negativo: menos $1,6 \%$ !

Se no interior a paisagem era essa, no exterior nossa imagem era a da insolvência. Chegamos à vergonha de ver bloqueadas nossas reservas no estrangeiro e confiscados os navios mercantes com a bandeira brasileira, em portos europeus.

A Revolução de março não foi, pois, apenas, uma necessidade quanto à ética administrativa ou quanto à preservação do regime democrático; mais que isto, foi medida de salvação nacional. E é por isso que seu caminho é penoso, e duros têm de ser seus instrumentos de ação. Não se salva um povo, uma nação, do caos, da irresponsabilidade mascarada de otimismo, senão através do sacrifício e nunca por meio de sortilégios. 


\section{FUNDAMENTOS DA POLITICA TRABALHISTA REVOLUCIONÅRIA}

A Revolução, pelos seus dois Presidentes, sempre afirmou que não veio em nome dos ricos contra os pobres, em favor dos patrões contra os trabalhadores.

A intriga que neste sentido se pretendeu fazer derivou da exploração capciosa de providências que os trabalhadores, como de resto tôda a Nação, tiveram de suportar, para que o processo de deterioração econômica do Brasil fôsse inicialmente contido e, depois, vencido.

Já o pranteado Presidente Castello Branco afirmava, no seu discurso de posse:

"A arrancada para o desenvolvimento econômico, pela elevação moral, educacional, material e política, há de ser o centro das preocupações do Govêrno. Com êsse objetivo, o Estado não será estôrvo à iniciativa privada, sem prejuizo, porém, do imperativo da justiça social devida ao trabalhador, fator indispensável à nossa prosperidade."

E logo a 10 de maio de 1964, falando de São Paulo para todos os brasileiros, disse êle:

"A Revolução não foi feita contra os direitos sociais dos trabalhadores. Pouco importa o que assoalham os ainda inconformados por haverem perdido os cofres públicos com que levavam, com sacrifício dos pobres, uma artificiosa e rendosa luta de classes. A verdade, porém, é que estamos interessados não apenas em conservar, mas também em aprimorar as normas de proteção ao trabalhador, promovendo os meios e instrumentos adequados à sua efetiva aplicação .... ...... Assim, na longa história das lutas, que não é apenas brasileira, mas universal, a Revolução não será um passo para trás, mas uma caminhada para a frente, nas justas e legítimas conquistas do trabaIhador.".

Desde cedo, por seu turno, o Presidente Costa e Silva, decidido a fazer da retomada do desenvolvimento o maior escopo do seu govêrno, enfatizou que, nêle, o homem seria o "centro de suas atenções e decisões".

Desenvolver o País, quer o Govêrno Revolucionário, mas o quer paralelamente à valorização do homem. Valorização permanente, que lhe dê melhores condições no mercado de traba- 
Iho, que the proporcione mais ser e não apenas o iluda através da panacéia de aumentos nominais de salários, insustentáveis, que o custo de vida destrói.

No campo do trabalho, natural é que essa diretriz revolucionária se projete numa definição doutrinária e na tomada de posições práticas.

\section{DEFINIÇÃO DOUTRINÁRIA - VISẢO DO TRABALHO}

O teólogo Gustave Thils, especulando sôbre a significação e a natureza do trabalho, em sua "Teologia das Realidades Terrestres" assim se expressa:

"Que significa o trabalho para o cristianismo? Não seria uma inevitável conseqüência do pecado original? Ou será uma graça divina, uma vocação, convidando o homem a operar com Deus neste mundo?

Será o trabalho um deus? Ou uma coisa? Ou uma mercadoria? Ou uma colaboração com Deus?"

Em sua longa trajetória, do escravagismo que produziu as maravilhas faraônicas e a civilização greco-romana, aos dias hodiernos, o trabalho passou por notáveis mutações.

Ainda hoje, porém, se discute o trabalho em face do capitalismo privado ou do socialismo, até aqui mero capitalismo de Estado.

Há os que vêem no trabalho simples fator de produção, neutro, utilizável como se utilizam as matérias-primas e adquirível pelo mais baixo preço que fôr possível. Assim fazem os que só se interessam pelo homem enquanto fornecedor de trabalho, interêsse que está condicionado à teoria da maximização do lucro.

Esta ótica pode levar e necessàriamente leva, em certos casos, à opressão. Nos países subdesenvolvidos, com larga massa demográfica, o excesso de mão-de-obra, sobretudo nos campos, desequilibra o mercado em favor do detentor do capital. A liberdade de discutir condições de trabalho não é mais que um direito nominal. Ao trabalhador não se confere senão o direito de adesão à oferta patronal.

É nesse caso, especialmente, que a concepção do trabalho como simples mercadoria, cujo preço deve ficar ao sabor da lei da oferta e da procura, torna-se opressora do homem.

Há, de outra parte, os que advogamos para o trabalho a primazia no processo produtivo; os que o desejamos dignificado e, como tal, superior ao capital. 
Para nós, o trabalho não é nem mercadoria, nem um deus em si mesmo, isso para responder às perguntas de Thils. Por ser o mais nobre dos fatôres de produção, o trabalho requer proteção e segurança e garantia de justa remuneração, o que leva Charbonneau a asseverar que o "trabalho não é um instrumento de produção; é meio de viver."

Desta conceituação decorrem algumas conclusões inevitáveis, como:

19) o trabalho, não sendo mercadoria, deve ser realizado em liberdade, isto é, não pode ser impôsto ao indivíduo sem alternativa de opções;

29) o trabalhador deve receber salário justo, que, segundo a lição de João XXIII, na Mater et Magistra, Ihe proporcione nível de vida verdadeiramente humano e seja determinado levando-se em conta a produtividade do trabalhador, as condições econômicas da emprêsa e as exigências do bem comum;

3 ?) as condições do trabalho devem resguardar, no homem, a dignidade que Ihe é imanente e garanti-lo contra tôda sorte de infortúnios.

\section{O TRABALHO EM FACE DA PROPRIEDADE}

\section{A propriedade privada}

A Revolução Brasileira, em sua segunda fase, tem enfatizado, sistemàticamente, que "o Homem não pode ser olhado pelo Govêrno como simples abstração numérica ou mero fator mecânico."

Fazendo do Homem o centro de suas atenções e decisões, - Govêrno Costa e Silva, na área do trabalho, faz do humanismo social um poderoso instrumento a serviço da conciliação de propósitos entre o capital e trabalho, missão profundamente repudiada pelos extremistas e conservadores radicais.

Os comunistas e seus aliados da esquerda negam a compatibilidade de propósitos entre capital e trabalho. Querem no Estado totalitário o contrôle dos bens de produção e até dos bens de consumo. Fazem, por isso, da luta de classes a pedra de toque de sua campanha. Sustentam, simplesmente, que "a luta de classes representa a fôrça motriz do desenvolvimento da sociedade"; e a defendem, afirmando que: "Quanto mais vigorosa é a luta das classes oprimidas contra as classes exploradoras, quanto mais êxitos obtém a sua resistência aos opressores, tanto mais ràpidamente se manifesta, como regra, o progresso em todos os terrenos da vida social." 
Ajudam-nos, por paradoxal que pareça, os capitalistas imobilistas, que têm horror a qualquer intervenção disciplinadora e mediadora do Estado no campo econômico.

São os saudosistas da belle époque do capitalismo liberal, que desejam o Estado mero espectador passivo no mercado do trabalho; os que vêem, nos sindicatos, organizações intoleráveis de conspiradores contra os lucros, os que pretendem ter, no Estado, um aliado como instrumento de opressão e violência aos trabalhadores; os que, em suma, dariam razão a Marx ao identificar o Estado com "uma ditadura de classe ou de classes exploradoras".

Êstes, pela insensibilidade para os problemas sociais e pelas injustiças que causam, são os melhores aliados dos radicais.

Enquanto os comunistas e socialistas não-democráticos lutam pela rutura violenta da estrutura capitalista e sua substituição total pelo Estado, pregando o ódio entre empregados e patrões, êstes, quando dominados pelo radicalismo conservador, gostariam de construir a paz social à sua maneira, esmagando 0 trabalhador, negando-Ihe sequer o direito de ser ouvido.

Ora, a propriedade privada não é mais a cidadela de direitos monárquicos absolutistas e hereditários. Já não existe o jus utendi et abutendi dos tempos do capitalismo liberal, em que o Estado só intervinha para garantir as liberdades individuais, inclusive a do empregador contratar, como Ihe aprouvesse, o trabalho do assalariado. Liberdades individuais utópicas, pois, como já diz a conhecida frase de Lacordaire: "quando fracos e fortes se digladiam, a liberdade escraviza e só a lei liberta".

É dever do Estado intervir para proteger o mais fraco sem destruir o mais forte e para garantir a comunidade do seu todo. Tal intervenção, contudo, não se confunde com a proscrição da propriedade privada. Ao contrário, a propriedade particular deve ser altamente disseminada, pois, como afirma João XXIII na Mater et Magistra, "o direito da propriedade privada, mesmo sôbre bens produtivos, tem valor permanente, pela simples razão de ser um direito natural fundado sôbre a prioridade ontológica e final de cada ser humano, em relação à sociedade. Além disso, a História e a experiência provam que, nos regimes políticos que não reconhecem o direito da propriedade privada sôbre os bens produtivos, são oprimidas e sufocadas as expressões fundamentais da liberdade; é legítimo, portanto, concluir que estas encontram, naquele direito, garantia e incentivo".

Como se vê, claramente pôsto pela lucidez do grande $\mathrm{Papa}$ contemporâneo, até a liberdade do homem periclita quando êle 
não tem acesso à propriedade particular. De resto, só através dela o homem produz o máximo, no seu empenho de obter mais valor.

Há, entretanto, que ressalvar-se o sentido social da propriedade privada, em harmonia com o bem comum. Do contrário, não deve prevalecer. É o caso, por exemplo, dos latifúndios improdutivos, que devem desaparecer numa reforma agrária oportuna, bem como dos minifúndios de exploração antieconômica.

A propriedade privada não é, pois, intocável. Antes pelo contrário, deve ser permanentemente examinada à luz da sua função social, pois não pode sobrepor-se aos interêsses maiores da comunidade.

Daí deriva o direito, e muitas vêzes o dever, de o Estado intervir, sempre que o bem comum estiver em causa.

Conclusão pacífica e tranqüila é que o Estado deve proporcionar condições para a disseminação da propriedade privada, vale dizer, o acesso do maior número de pessoas a ela, caminho seguro da obtenção do mais ser e, conseqüentemente, da desproletarização do assalariado.

\section{A propriedade coletiva}

O confisco da propriedade, pelo Estado, constitui a maior fraude dêste século, como fórmula prometida de resguardar o homem das injustiças imanentes ao capitalismo liberal.

Em nenhuma das chamadas nações comunistas obteve-se, com a estatização da propriedade, a garantia de que o trabaIho não fôsse tratado como simples mercadoria, e o trabalhador como objeto da sociedade e não como seu sujeito. A experiência tem demonstrado que não desapareceram as classes e que privilégios e funções parasitárias são a conseqüência natural do poder despótico.

Algumas dessas nações, notadamente as que realizaram a Revolução partindo do campo para as cidades, sacrificaram desde logo, às conveniências políticas, os postulados marxistas e permitiram, aos camponeses, a posse de pequenas propriedades, quando não distribuíram entre êles, à guisa de reforma agrária, as grandes propriedades confiscadas.

O malôgro periódico da União Soviética, na agricultura, serviu de exemplo histórico. O stakanovismo nas fábricas e a reCente permissão, nos Kolkhozy, de utilização de uma pequena faixa pelo colono, a seu alvedrio, seguido da venda do seu pro- 
duto no mercado livre, são bem o testemunho prático de que é preciso aliar, no homem, o trabalho ao sentimento da posse do que produz pelo seu esfôrço. Só assim êle se persuade em tomar um maior interêsse pessoal na sua tarefa.

O notável exemplo dos Moshavim em face dos Kibutzim em Israel reforça a convicção de que o ideal é associar, ao trabalho do homem, a garantia da maior ou menor remuneração em face da maior ou menor dedicação ou da capacidade individual.

O Socialismo, que confisca a propriedade privada e a coletiviza, violenta um direito natural e desestimula os homens.

Por isso, até mesmo os regimes comunistas estimulam a iniciativa individual. A "Nova Política Econômica". de Lênin, conquanto fruto de "posição tática", é um exemplo, que Stalin destruiria pelo puro e simples esmagamento dos proprietários rurais, quando já não corresse o risco do colapso da produção agropecuária.

Outro exemplo está na concessão iugoslava à posse privada da terra, que encontra eco na China de Mao-Tse-Tung, na fase da implantação do seu regime.

A propriedade coletiva leva, inevitàvelmente, à opressão do trabalhador, que se desinteressa do resultado, já que o monopólio da emprêsa, pelo Estado, fêz com que as leis da economia de mercado fôssem substituídas pelo monopólio do trabalho, exercido pelo único proprietário, que é o Estado.

Milovan Djilas, no seu excelente livro "A Nova Classe", confessa desalentado que o uso simultâneo do monopólio material e político coloca a fôrça de trabalho na situação, ela mesma, de propriedade da burocracia dominante, que tem o poder incontrastável de estabelecer condições de trabalho e as relações entre salários e lucros.

"O sistema - diz o velho líder comunista iugoslavo leva invariàvelmente à falta de interêsse da parte dos verdadeiros produtores, isto é, dos trabalhadores.

Leva, também, a uma baixa qualidade da produção, a um declínio real na produtividade e no progresso tecnológico e ao atraso da fábrica. Os comunistas estão constantemente lutando por uma produtividade maior por parte dos trabalhadores, individualmente, sem se ocuparem da fôrça de trabalho como um todo. 
Em tal sistema, os esforços para estimular o trabalhador são inevitáveis e freqüentes. A burocracia oferece tôda sorte de prêmios e recompensas, para contrabalançar a falta de interêsse. Mas enquanto os comunistas não modificarem o sistema em si, enquanto mantiverem seu monpólio sôbre todo o direito de propriedade e todo o Govêrno, não poderão estimular o trabaIhador individual, e muito menos a fôrça trabalhadora como um todo."

Usado como objeto e não como sujeito da economia comunista, o trabalhador desinteressa-se do resultado do seu trabaIho. O Estado, em contrapartida, impõe-lhe contrôles rígidos: cota de produção, tarefas mínimas, confisco e até a pena capital para os "crimes contra o socialismo", tidos como tal a simples retenção, pelo colono, de uma parte, do que êle produziu, maior que a permitida pelo Estado.

Para vencer os resistentes, o poder tirânico se exerce em tôda a sua brutalidade. É tristemente célebre o monumento a uma criança que denunciou seu pai, um camponês, de "roubo de propriedade socialista", porque êle, para alimentar sua família, reteve cereais além da cota que Ihe era fixada.

Por outro lado, as medalhas, fazendo pendant com as gratificações de produtividades individual, a experiência de participação nos lucros, adotada na lugoslávia, os estímulos diversos não são capazes de alterar o comportamento coletivo. Mas tão logo os governos comunistas permitem uma brecha na ortodoxia marxista e, como no caso da agricultura soviética, proporcionam oportunidade concreta à iniciativa individual no trabalho, o resultado não se faz esperar, a produtividade e, conseqüentemente, a produção aumentam.

Neste sentido, vale a pena transcrever, ainda uma vez, as afirmações de Djilas, em "A Nova Classe", ao tratar da coletivização imposta por Stalin:

"O confisco da propriedade de outras classes, especialmente dos pequenos proprietários, provocou a queda da produção e o caos na economia, mas isso não teve conseqüências para a nova classe. Muito mais importante para ela, como para todos os proprietários na história, foi a conquista e a consolidação dessa situação. A classe usufruía a propriedade que conquistara, embora a nação perdesse a liberdade. 
Não há estatísticas dignas de fé, que confirmem isso, mas a evidência demonstra que as culturas por acre na U.R.S.S. não aumentaram em relação às culturas na Rússia tzarista e que os números relativos à pecuária ainda não se aproximam das cifras pré-revolucionárias.

As perdas nas culturas agrícolas e na pecuária ainda podem ser calculadas, mas as perdas humanas, os milhões de camponeses que foram postos em campo de trabalho forçado, são incalculáveis."

Tudo isso prova, após meio século de aventura socialista, que é próprio do homem ser proprietário e que a propriedade particular é, de fato, um direito natural precioso.

\section{A REMUNERAÇÃO DO TRABALHO}

Já estabelecemos a premissa de que o salário deve ser justo. A frase, em si mesma, é vaga e, segundo alguns economistas, ingênua; mas serve. Impõe-se, contudo, desde logo, responder a uma pergunta:

- Pode haver salário justo?

É evidente que a resposta será obrigatòriamente não, para os comunistas. Nenhum dêles pode admitir que a paga das horas de trabalho de um operário corresponda exatamente ao seu valor. Se o admitisse estaria negando o fundamento do marxismo, como teoria econômica: a mais-valia, que não é senão a diferença, para os marxistas, entre o custo da fôrça de trabalho e valor real da sua contribuição para a produção. Logo, para um socialista, conceber que o salário pode ser equivalente a essa contribuição, seria renegar sua crença no que ela tem de básico e vital.

Nós, contudo, afirmamos que o salário pode, e deve, ser a justa remuneração do que produz o trabalhador.

A citação anteriormente feita da grande encíclica do Papa João XXIII parece-nos o que de melhor se estabeleceu até aqui, pois, segundo suas palavras, o salário deve ser proporcional ao "efetivo concurso dos trabalhadores para a produção" e levar em conta "as condições econômicas das emprêsas e as exigências do bem comum".

E ainda aduz o Santo Padre: "É claro que os critérios acima valem sempre e em tôda parte. Contudo, não é possível determinar a medida em que devem aplicar-se, sem atender à riqueza disponível". (o grifo é nosso). 
Nenhum pensamento mais lúcido; nenhum mais elucidativo. O salário justo é, pois, aquêle que equivale à contribuição da fôrça de trabalho no processo produtivo, levadas na devida consideração as condições da emprêsa e a riqueza disponível. Só assim, poderemos entender por que, a tarefas iguais, correspondem pagamentos desiguais, de uma nação para outra, ou até dentro da mesma nação.

Deve-se isso às condições diversas das emprêsas e das nações, quanto à riqueza disponível.

Outra pergunta que se impõe responder desde logo é:

- Deve haver uma política nacional de salários?

Os ortodoxos do não-intervencionismo do Estado sustentam, com extremo vigor, que o salário é matéria em que só podem e devem ser ouvidos o empregador e o empregado, o sindicato patronal e o da categoria profissional correspondente, pois salários, custo e preços devem ser deixados à livre ação da concorrência no mercado.

Ora, a determinação do salário através das pressões sindicais sôbre os patrốes também pode levar, e normalmente leva, a injustiças. De um modo geral, por exemplo, se a determinação dos salários é consequeência de greve, o resultado traduzirá, ao mesmo tempo, o desgaste da resistência de ambas as partes. Assim é que a tendência de concessão dos empregadores cresce na razão direta da duração da greve, enquanto a capacidade de resistência dos empregados decresce na mesma razão. Na dependência, pois, da capacidade econômica do sindicato, para vencer os dias de greve, e a dos empregadores, para suportarem os prejuizos decorrentes, é que se chegará a um acôrdo, se o Estado se mantiver passivo espectador.

Disso decorrerão, inevitàvelmente, injustas situações relativas, quanto aos aumentos conseguidos por esta forma, pelas diferentes categorias profissionais, dadas as suas diversidades quanto ao poder de barganha.

A pressão de um sindicato forte pode resultar até mesmo na concessão de aumentos muito superiores à produtividade da emprêsa, o que é mau para a nação.

É como diz Adolf A. Berle:

"O sapato, então, muda de pé: ao invés da exploração do trabalho por um empregador ou produtor, baseada no seu poder econômico, o grupo trabalhista pode tentar explorar tanto o empregador como o público." Entrementes, categorias profissionais fracamente organizadas ficarão à mercê dos seus patrões. 
Criar-se-ia, assim, uma classe de trabalhadores privilegiados, em face de outra de explorados.

Tal injustiça, já de si inadmissivel, torna-se intolerável nas economias agredidas pela inflação, já que os aumentos desproporcionais aos privilegiados agravariam a inflação, cujos resultados nefastos esmagariam, cada vez mais, os trabalhadores sem poder de barganha.

Se o Estado assistir, passivamente, a êsse processo, cavará sua ruína.

Como evitá-la, é a grande preocupação dos que debatem os remédios possiveis. Em que medida deve o Estado intervir, para, não permanecendo ausente, não se fazer presente até 0 limite da desfiguração da economia de mercado?

Em primeiro lugar, para ter a medida exata da sua atuação, - Govêrno deveria estar equipado para responder a algumas indagações, por exemplo:

- Como influem os sindicatos na fixação dos salários?

- Que efeitos têm os aumentos na produtividade e na política de emprêgo?

- Os aumentos salariais decorrem do balanço das fôrças da economia, ou atendem a considerações politicas dos líderes sindicais?

As teorias do salário não têm respostas precisas para essas perguntas. E como não as têm, pode-se concluir "a fortiori" que a ausência de poder arbitral, pelo Estado, deixa indiscutível margem para transformar em prováveis as injustiças possíveis.

Destarte, o papel de juiz do Estado, que a tantos horroriza, teria a excepcional vantagem de resguardar a eqüidade, que é parte da justiça social.

Isto começa a ser reconhecido.

Um liberal do porte de Adolf Berle, depois de comentar episódios incomuns, em que o Presidente Kennedy interveio para impedir aumento dos preços do aço, pelos patrões, bem como para combater uma greve de mecânicos de vôo, assim conclui:

"Em futuro mais distante, é difícil não se prever o estabelecimento do princípio de arbitramento compulsório nas indústrias cujo funcionamento ininterrupto é de interêsse público - um princípio ainda não estabelecido na república econômica americana, que ainda opera baseada na ficção de que os contratos de trabalho englobam os resultados de uma negociação de mercado livre." 
Não é outro o exemplo contemporâneo, mesmo em nações governadas por trabalhistas, como a Inglaterra, e democratascristãos, como o Chile.

O "Labour Party", na Grã-Bretanha atual, chegou ao remédio drástico, que foi o congelamento de salários e preços, política que abandonou em favor do contrôle dos aumentos pelo Estado. Ainda mais: foi um Govêrno trabalhista que teve a coragem de complementar êsse contrôle através da limitação do direito de greve, imprescindível à execução da política de contrôle salarial.

Claro está que tal posição deflagraria verdadeira rebelião dos sindicatos inglêses, que jamais sofreram tal intervenção, mesmo nos Governos conservadores.

É que, quando está em jôgo a preservação do país, os políticos íntegros e honestos não se preocupam em ser pessoalmente agradáveis a qualquer classe, mas dignos do papel de dirigentes nacionais, com tôdas as responsabilidades decorrentes, entre as quais a fidelidade ao país não é a menor.

Nos países citados, como no Brasil, havia que vencer 0 grande inimigo do poder aquisitivo dos trabalhadores, que é a inflação. Daí uma política de contenção salarial, pois é fora de dúvida que o salário pode ser fonte autônoma de inflação, se aumentado acima dos limites da produtividade da emprêsa, já que os salários se refletem na política de desenvolvimento econômico e social de modo a não serem ignorados.

Decisões que afetam o nível e a estrutura dos salários têm pronta repercussão nos custos de produção, na produtividade, nos preços de consumo, na balança de pagamentos e na oferta de empregos.

Em conclusão, pode afirmar-se que, ao menos quando parte de uma estratégia de combate à inflação, é imperativa a adoção do arbitramento salarial compulsório, pelo Estado: e, em qualquer caso, êsse arbitramento acabará por impor-se, em nome da segurança da comunidade, para regular salários das emprêsas cujo funcionamento ininterrupto é vital ao interêsse público.

\section{SALÁRIO-MINIMO}

O Estado, em alguns casos, não utiliza o arbitramento compulsório na determinação dos salários em geral, preferindo influir através da política de remuneração dos seus próprios servidores e do estabelecimento de níveis de salário-mínimo. 
Nem todos os economistas se põem de acôrdo, quanto à conveniência e sobretudo à eficiência da fixação de valôres de salários-mínimos, por lei.

Os clássicos sustentam que uma lei que fixa salário-mínimo é, na melhor das hipóteses, uma faca de dois gumes, ou, como afirma Hazlitt: "uma arma limitada ao combate do mal dos salários baixos, cujo possivel bem sobrepor-se-á ao possível mal, sòmente na proporção dos seus modestos objetivos".

Para seus contestadores, a lei que impõe salário-mínimo leva ao desemprêgo, pois ninguém que valha menos que 0 salário estipulado será ou permanecerá contratado. Por outro lado, indústrias de pequeno porte serão condenadas à falência. Não se diga, argumentam êles, que uma indústria não deve subsistir, se não puder pagar senão salários de fome, pois ainda há margem para opção entre o baixo salário e o desemprêgo. Se essa indústria falir, compelida pelo nível de salário-mínimo que não pode pagar, pior para os trabalhadores, que se desempregam; pior para os consumidores, que sofrerão a perda do produto.

Todos os países latino-americanos têm leis estabelecendo e regulando o mecanismo do salário-mínimo.

A justificação da medida está no proporcionar aos trabaIhadores o mínimo de proteção, visando à sua participação na renda nacional.

Como, em geral, tais nações têm excesso de mão-de-obra no mercado de trabalho e, comumente, essa mão-de-obra é não qualificada, a proteção dada pela determinação de salário-mínimo é efetiva. Se, ao contrário, a oferta de trabalho sobrepujasse a demanda, o estatuto de salário-mínimo não teria cabimento, pois a disputa do trabalhador pelo patronato levaria automàticamente ao oferecimento de condições de atração.

Nos países em desenvolvimento, onde há desequilíbrio no mercado de trabalho em desfavor da oferta, a lei de salário-mínimo é estatuída como forma de aumentar o nível de renda dos trabalhadores, que dificilmente podem prover a sua subsistência e a de seus dependentes, segundo um nível decente de vida.

Ademais, a baixa renda dos assalariados é um obstáculo ao próprio desenvolvimento.

Assim, consideradas a fraqueza de poder de barganha dos sindicatos e a disparidade crescente entre o aumento da população e da oferta de empregos, o salário-mínimo obrigatório transforma-se em um dos principais objetivos da política nacio- 
nal de desenvolvimento social e econômico, pois além de influir substancialmente no nível e na estrutura dos salários em geral, que estão muito próximos do mínimo, abre aos trabalhadores o acesso à participação nos resultados do crescimento econômico. Além disso, o salário-mínimo contribui para a expansão da produção, pelo seu efeito incrementador da demanda.

Em muitas nações entende-se por salário-mínimo, como no Brasil, o estritamente necessário à subsistência de uma pequena família, de modo a cobrir suas necessidades, inclusive as sócio-culturais.

A partir dêsse conceito, podem causar-se frustrações, uma vez que os países em desenvolvimento não têm como garantir, desde logo, tal nível de salário-mínimo que permita a subsistência normal de uma pequena família, habitação condigna, assistência educacional aos filhos, bem como recreativa a todos.

É evidente que não se pode distribuir mais riqueza do que a existente, nem pagar à fôrça de trabalho mais do que ela produz.

Desgraçadamente, no Brasil, metade da fôrça de trabalho não percebe mais que um salário-mínimo, o que faz crescerem de importância as decisões quanto ao seu nível.

Em uma economia livre, o salário-mínimo visa a estabelecer uma proteção para o trabalhador, mas não é um sortilégio. Ele tem um importante papel relacionado com o desenvolvimento econômico e social, já que tem reflexos acentuados nos custos da produção e na política de investimentos e de emprêgo. Daí por que "os níveis de salário-mínimo - como recomendado pelo seminário da OEA, de 1967, em Tegucigalpa deverão estabelecer-se conforme o melhor equilíbrio entre as necessidades dos trabalhadores e o ritmo de desenvolvimento econômico de cada país".

O difícil, sem dúvida, é estabelecer o justo equilíbrio. Parece fora de dúvida, porém, que a melhor maneira de
elevar salários é aumentar a produtividade do trabalho, o que so pode conseguir:

- pela automação;

- por novas invenções e aperfeiçoamentos;

- por uma administração mais eficiente;

- e, finalmente, por meio de maior operosidade como conseqüência de melhor treinamento.

nações, a automação vale como um "boomerang" para as 
superpovoação nos campos. Não teríamos como, em curto prazo, absorver a mão-de-obra tornada ociosa.

O remédio é de administrar-se cautelosamente.

A administração e as invenções escapam, de maneira geral, ao trabalhador assalariado, que só no treinamento próprio pode confiar para a melhoria da sua produtividade e do seu próprio valor.

A formação profissional de mão-de-obra é, em conseqüência, a política mais acertada, para que o trabalhador adquira "mais valor", especialmente sob as condições prevalecentes no Brasil, onde a oferta de empregos excede a demanda $e$, no entanto, há desemprêgo, causado pela falta de qualificação profissional dos postulantes, incapazes de desempenharem as funções oferecidas no mercado de trabalho.

É uma grosseira ilusão supor que se pode aumentar, realmente, salário através de decreto. Sòmente a valorização do homem lhe proporcionará melhores salários, porque só o aumento da produtividade incrementa a riqueza.

\section{OS SINDICATOS}

Um dos indicadores de regime democrático é o sindicato. Quanto mais atuante, mais legítima a democracia, em cuja dinâmica de fôrças a organização do trabalho exerce papel de relêvo.

Nos países totalitários, os sindicatos são um lôgro, ou como o diz com muita propriedade Milovan Djilas: "espalhadores de ilusões", encarregados de pregar o conformismo entre os trabalhadores, pois o seu principal papel é de ordem política. No preâmbulo dos Estatutos dos Sindicatos da URSS, adotados em março de 1959, há a seguinte passagem, que é esclarecedora:

"Os sindicatos soviéticos, que são organizações sociais da massa, sem caráter de partido, agrupam, à base da filiação voluntária, os empregados e trabalhadores de tôdas as profissões, sem distinção de raça, nacionalidade ou religião.

Os sindicatos soviéticos realizam todo o seu trabalho sob a direção do Partido Comunista da União Soviética, que é a fôrça que organiza a sociedade soviética. Os sindicatos da URSS congregam os trabalhadores e empregados em tôrno do Partido, que os mobiliza para lutar pela edificação da sociedade comunista". (o grifo é nosso.)

Pode ver-se, claramente, como os sindicatos são projeções do Partido único, que detém o monopólio político e, conse- 
qüentemente, impõe a sua vontade aos trabalhadores. Por isso é que Djilas, que os conhece tão bem, nêles vê autênticas "organizações patronais", pois os sindicatos em verdade representam o único potentado, que é a oligarquia política.

Ora, considerando-se o número limitadíssimo de militantes comunistas, em face da população da União Soviética, fácil é concluir que os comunistas, membros do Partido, existentes nos Sindicatos, serão insignificante minoria. Se, pois, é através dessa minoria que o Estado controla as organizações sindicais, resulta indiscutível a sua subordinação ao Partido, vale dizer, ao Estado.

De fato, isso é conseqüência inevitável da concepção teórica do socialismo, como uma sociedade sem classes, na qual todos se dedicam ao objetivo comum de aumentar o bem-estar da comunidade, já não havendo grupos em conflito: os trabathadores contra os proprietários. Já que os trabalhadores são também, por hipótese, os donos da propriedade, que é coletiva, as diferenças que surgem entre a mão-de-obra e a direção da emprêsa não se consideram como antagônicas em relação ao objetivo fundamental, que é a produção, mas antes como simples acidentes de relações humanas na emprêsa.

Daí se compreende por que os sindicatos soviéticos têm relevante papel na administração dos serviços culturais e recreativos.

Sôbre o assunto, assim se expressa Alec Nove, no seu livro "A Economia Soviética":

"A afirmação de que os sindicatos soviéticos não são absolutamente sindicatos é ouvida com freqüência no Ocidente. É de todo claro que não são independentes do Estado ou do Partido e que seu fito é o de organizar os trabalhadores para a execução da diretiva estatal e partidária. Contra tal afirmação diz-se, às vêzes, que sob as condições soviéticas é irracional esperar conflitos entre os diretores e a mão-de-obra, porque os diretores também são empregados do Estado (e, na verdade, membros do mesmo sindicato) e que os sindicatos, na verdade, têm poder para proteger seus associados contra atos arbitrários ou contra negligência por parte da direção. $\mathrm{Na}$ verdade, tais podêres acham-se presentes e são impressionantes. A dificuldade, entretanto, é que a tarefa do sindicato, como "correia de transmissão" das diretivas econômicas partidárias, muitas vêzes é difícil de conciliar com seus 
deveres de "proteção" frente a seus associados e, devido ao elemento forte de contrôle partidário, em qualquer conflito de lealdade os funcionários respondem primeiro, e acima de tudo, aos que estão por cima dêles, que na verdade os nomeiam e preparam suas "eleições", ao invés dos associados. Assim, se o serão obrigatório ou o trabalho em dia de repouso fôr escolhido como meio de acelerar o cumprimento do plano, é inteiramente improvável que o setor sindical deixe de apoiar a direção, sejam quais forem os sentimentos de seus associados. Em outras palavras, ao avaliar as fôrças econômicas em operação na União Soviética, seria errôneo ver os sindicatos como qualquer tipo de grupo de pressão independente, embora providências sejam tomadas comumente pelo setor sindical local para garantir, por exemplo, que uma gestante receba as férias pagas a que tem direito pela lei, ou que um carpinteiro de graduação IV não seja injustamente rebaixado, embora até mesmo nisso 0 sindicato muitas vêzes negligencie seus deveres.

Os sindicatos administram os fundos de segurança social e os benefícios concedidos aos associados são muito maiores dos que aos não-sócios, o que ajuda a explicar o motivo pelo qual a vasta maioria dos trabalhadores capacitados pertence aos sindicatos. Os lavradores do kolkhoz e os artesãos cooperados não têm sindicato e não recebem benefícios de segurança social de fontes estatais; os kolkhozy e as cooperativas têm de fazer seus próprios arranjos para socorrer seus associados em dificuldades.".

Além de tudo o que já se pôs em evidência, quanto à vida sindical soviética, depreende-se da citação do economista inglês que não há sindicatos rurais na URSS, cabendo o seu papel às cooperativas.

De resto, é interessante notar o porquê da acentuada sindicalização dos trabalhadores soviéticos (acima de $90 \%$ dos trabalhadores nas indústrias).

A missão da Organização Internacional do Trabalho que, em 1959, foi à URSS para examinar o sindicalismo soviético, assim se expressou em seu relatório:

"La situación del trabajador como afiliado a un sindicato es difícil de describir. Cabe perguntarse si la elevada proporción de afiliados a los sindicatos entre los 
trabajadores significa que se está ejerciendo mayor presión sobre ellos para que se afilien a los sindicatos que en muchos otros países. Se trata de una custión de comparación sobre la cual la Misión no puede formular una opinión. En todo caso, no hay que olvidar la influencia de la educación y del medio social en los trabajadores. Se explicó a la Misión que la afiliación a los sindicatos no es obligatoria, y que si no puede persuadirse con argumentos a un trabajador para que se afilie a un sindicato no se ejercerá sobre el coerción alguna. Es evidente que se alienta a los trabajadores a que se afilien a los sindicatos, que se ejerce una fuerte influencia moral sobre ellos para que así lo hagan y que existen incentivos apreciables para que se afilien. Tal vez estos factores basten para explicar el hecho del elevado numero de afiliados a los sindicatos."

Já nos países democráticos o quadro é diverso; os sindicatos são atuantes, como instrumentos de pressão para obter o equilibrio de fôrças nas relações de trabalho.

A história do trabalhismo mostra que o caminho percorrido foi pontilhado de obstáculos; está, até mesmo, manchado do sangue dos que foram sacrificados na luta por melhores condições de trabalho. Mas foi uma extraordinária conquista.

O sindicato sem fôrça ou virtualmente inexistente é sintoma de democracia periclitante. Os que não Ihe alcançam o papel, desejam-no inócuo e inativo, para que tôdas as injustiças possam ser cometidas sem resistência e reação.

O papel do sindicato é, porém, o de tornar fortes, pela representação de todos, os trabalhadores que isoladamente são fracos; é pleitear favoráveis condições de trabalho, melhores salários, participação dos trabalhadores nos frutos da emprêsa; é assegurar, através sobretudo dos contratos coletivos de trabalho, a obtenção, pelos trabalhadores, de uma porção justa de riqueza que êles ajudam a produzir; é, finalmente, dar segurança ao trabalhador e, conseqüentemente aos seus dependentes.

Desempenhado, com equilibrio, êsse papel, favorece realmente o trabalhador e contribui para o estabelecimento da justiça social. Atente-se, por exemplo, para esta afirmativa de A. Berle, no livro já citado: "Na verdade, a sindicalização do trabalho e a negociação coletiva foram uma das maiores causas da adequada distribuição de renda nos Estados Unidos." 
Quando, porém, o sindicato exorbita de suas funções legítimas, passa a ser nocivo instrumento de uma política anti-social. Assim é quando pleiteia aumentos salariais acima da produtividade de emprêsa; quando envereda pela ação política; quando utiliza o direito de greve, que é legítimo, não para compelir o mau patrão à aceitação do pleito justo, mas para intimidar e obter vantagens excessivas, numa prática bem aproximada da chantagem.

Os êxitos do sindicato, assim obtidos, são apenas aparentes, além de significarem injustiça para com os próprios trabaIhadores, já que nem todos são igualmente poderosos para forçarem os patrões a concordarem com aumentos excessivos.

Assim, de pronto, pode concluir-se que algumas categorias de trabalhadores, por terem maior poder de pressão e de barganha, graças à natureza essencial do que produzem ou do serviço que prestam à comunidade, conseguem aumentos salariais acima do valor real do mercado, em detrimento dos trabalhadores cujos sindicatos são fracos. Além da injustiça flagrante, os resultados práticos, mesmo para os beneficiados, são efêmeros.

Com efeito, a conseqüência natural será a transferência, pelas emprêsas atingidas, da carga do aumento salarial para os consumidores, que são em grande parte os próprios trabalhadores. É como diz Hazlitt: "Assim, a exploração do capital pelo trabalho poderá, quando muito, ser apenas temporária. Logo chegará a um fim."

A greve política é outra forma anti-social da atividade sindical, que deve ser impedida rigorosamente pelo Govêrno.

Para ser autêntico e útil à democrácia, o movimento sindical deve ser, como o queria Gompers, triplicemente livre:

- do Govêrno;

- dos patrões;

- e da política partidária.

Entende-se por liberdade, quanto ao Govêrno, o que estabelece a Constituição brasileira:

"Art. 166. E livre a associação profissional ou sindical; a sua constituição, a representação legal nas convenções coletivas de trabalho e o exercício das funções delegadas do poder público serão regulados em lei. 
$\S 1$ ํ. Entre as funções delegadas a que se refere êste artigo, compreende-se a de arrecadar, na forma da lei, contribuições para o custeio da atividade dos órgãos sindicais e profissionais e para a execução de programas de interêsse das categorias por êles representadas.

$\S 2$ ? E obrigatório o voto nas eleições sindicais."

O privilégio de exercer função delegada, do poder público, implica na responsabilidade do sindicato, perante êsse poder, pela aplicação da receita decorrente da contribuição compulsória.

Muitos defendem a tese de que essa contribuição é espúria e deve acabar. Ora, os sindicatos brasileiros, em número superior a 5.000 , não têm todos condições de subsistir, se lhes fôr retirada a renda proveniente da contribuição obrigatória. Um grande número seria afetado e entraria em colapso, a menos que passasse a receber auxílios de fontes nocivas, o que seria difícil de evitar.

Assim, embora inconveniente, a contribuição sindical é, na pior das hipóteses, um mal necessário.

Para evitar que o sindicato seja prêsa fácil da política (normalmente dos comunistas) a lei ordinária brasileira criou obstáculos, entre êles a exigência de que os candidatos a postos eletivos sindicais não pertençam a partidos políticos ilegais, nem lhes defendam ostensivamente os princípios.

Em linguagem comum, chama-se a isto, por analogia com a legislação getulista do "Estado Nôvo", de "atestado ideológico".

A impugnação, baseada nessa exigência, não só é antidemocrática como ineficiente, pois os extremistas preparam seus dirigentes de modo a de preferência não os expor claramente. Depois de eleitos é que êles se revelam instrumentos dos comunistas.

A melhor política, parece-nos, é a da liberdade com responsabilidade, isto é, em vez de impugnar-se a eleição, com fundamento em informações muitas vêzes precárias ou facciosas, deve-se acompanhar rigorosamente a atuação das lideranças sindicais, de sorte a expurgá-las no exato momento em que se comprovar, já agora por fatos, a sua atuação subversiva, a serviço da política marxista.

Ressalta, dai, a importância da formação de líderes sindicais atuantes, mas sérios e honestos nos seus propósitos; sufi- 
cientemente preparados, para conduzirem seus companheiros na luta por melhores condições de trabalho; necessàriamente corajosos, para enfrentarem as incompreensões que, com freqüência, se traduzem em perseguições e violência por parte de patrões retrógrados.

Por fim, é urgentemente imperativo que as organizações democráticas dos trabalhadores, nos países em desenvolvimento, estejam preparadas para participar do planejamento nacional de desenvolvimento econômico e social, fazendo valer os legítimos direitos do trabalho.

Neste sentido entende-se proveitosa a participação dos sindicatos na vida política nacional, sendo dever dêles contribuir também para o desenvolvimento, proporcionando treinamento e aperfeiçoamento para a mão-de-obra, bem como incutindo nos trabalhadores o senso de responsabilidade pelos destinos da sua nação.

\section{O PAPEL DA EMPRESA}

Karl Marx, ao criticar o capitalismo vigente no século $X I X$, levantou algumas premissas, em que se baseou para vaticinar o seu fim. Sustentava êle que o processo de auto-condenação do capitalismo levaria inapelàvelmente:

- à acumulação do capital e da riqueza em um pequeno grupo de proprietários, espécie de ilha em meio ao oceano de proletários e camponeses vivendo no mais baixo nível de subsistência;

- à ausência do mercado interno, que obrigaria à aventura imperialista;

- às crises periódicas e sucessivas, derivadas da concentração da riqueza em poucas mãos privilegiadas.

O modêlo atual do neocapitalismo desmentiu o profeta Marx, segundo a lição de A. Berle:

19) porque não permitiu a concentração dos bens em poucas mãos

As sociedades anônimas modificaram totalmente 0 panorama do capitalismo "manchesteriano". MiIhões de proletários tornaram-se acionistas das "corporations", participando de sistemas de seguro e da previdência social. Com o crescimento da riqueza, as rendas passaram a ser cada vez mais distribuídas através, inclusive, do impôsto sôbre a 
renda. Como resultado, o modêlo neocapitalista desproletarizou os trabalhadores, alçando-os à condição de classe média urbana e rural;

29) porque não permitiu que a riqueza detivesse o monopólio do poder

Os capitalistas sabem que o monopólio do poder - característica dos Estados Socialistas - é tão desastroso quanto o da propriedade.

Na URSS, por ironia com a previsão de Marx, é que o "Govêrno é o comitê executivo dos detentores do capital e da propriedade".

O poder temporal, nas democracias neocapitalistas, coloca-se acima, quer do poder econômico das emprêsas, quer da riqueza.

É fôrça reconhecer, contudo, que o malôgro das previsões pessimistas de Marx decorreu da modificação do capitalismo, que foi capaz de corrigir os seus erros do período do "laissez-faire". Infelizmente, no Brasil, a emprêsa privada nem sempre pode comparar-se às emprêsas neocapitalistas que têm como função principal a prestação de serviços à comunidade, a cuja necessidade real devem satisfazer, além de funcionarem como um mecanismo de redistribuição da renda.

"Não se pode dizer - afirma o Padre Fernando Bastos de Ávila - que a emprêsa, no Brasil, tenha desempenhado estas funções de modo satisfatório; precisamente por isto ela se encontra em crise. No Brasil, a emprêsa é capitalista, ou neocapitalista, na sua estrutura e no seu funcionamento. $\mathrm{Na}$ sua estrutura, a emprêsa conserva uma estrutura monárquica. O poder, a hegemonia do processo produtivo é deferida ao capital. No seu funcionamento, ela funciona primordialmente como um mecanismo de lucro, muitas vêzes, de lucros excessivos, inúmeras vêzes sem preocupação pelos setores prioritários, e muitas vêzes sem preocupação pela produtividade, pela mais racional utilização de bens raros. Mesmo produzindo mal, mesmo produzindo bens que a propaganda artificiosamente impõe ao público, ela continua a funcionar, porque seu interêsse é de dar lucro. Ora, uma tal emprêsa podia funcionar, sem maiores percalços, no clima de uma sociedade capitalista, de absoluta liberdade. Em tal clima, ela opera exclusivamente à base do princípio: reduzir o preço de custo e aumentar o preço de venda, isto é, o princípio do lucro. Acontece, porém, que êste clima não existe mais; esta atmosfera capitalista é Cada vez mais rarefeita. O Estado interfere no processo, fixan- 
do salários-mínimos e tabelando preços. O Estado, manipulando a política fiscal e cambial, sabe que pode expandir e estrangular indústrias. Por outro lado, as organizações sindicais e as correntes de opinião pública cada vez criam maiores dificuldades à hegemonia do capital. Nestas condições, quer nos parecer que a emprêsa no Brasil se encontra diante desta alternativa incontornável: ou ela se torna progressivamente, mas ràpidamente, comunitária, ou será absorvida por uma forma qualquer de socialismo estatal.

Se tal dilema é verdadeiro, impõe-se à emprêsa no Brasil uma reforma básica que é tornar-se a emprêsa comunitária, isto é, com a participação crescente de tôda a comunidade da emprêsa, capital, direção, técnica e trabalho, na própria vida da emprêsa, para usar a expressão da encíclica "Mater et Magistra".

O retrato feito pelo Padre Ávila é correto, pois a emprêsa brasileira ainda sofre, em larga extensão, os males de uma organização monárquica absolutista e hereditária. Os trabalhadores não são admitidos na discussão daquilo que, em última análise, significa a sua própria sorte, o seu destino. São êles, caracterizadamente, objetos da ação patronal, sem qualquer interferência nas decisões que os afetam.

Assim, o antagonismo entre as classes se agrava e disso tiram partido os comunistas, cuja inteligente atuação mascara, freqüentemente, os objetivos políticos e ideológicos através da utilização dos postulados da justiça social.

Como já afirmamos, a luta de classe é a matéria-prima da agitação comunista. Já dizia o Manifesto de 1848: "a história da Sociedade é a história da luta de classe". Se queremos batidos ou enfraquecidos os comunistas, devemos construir uma sociedade onde os conflitos sociais não tenham campo para desenvolver-se.

Ora, o conflito social está intimamente ligado às relações de trabalho. As tensões trabalhistas são, em geral, expressões das tensões sociais e vice-versa.

O papel, pois, que a emprêsa, privada ou pública, exerce no conflito social é muito relevante, para que fique a critério exclusivo de seus proprietários.

Êste conceito não deve escandalizar o patronato brasileiro mais do que aos militares franceses terá chocado o pensamento, nada obstante justo, de Clemenceau, ao dizer, em 1886 , que a guerra era assunto muito sério para ser confiada apenas aos generais. 
A visão do grande estadista antecipou-se à conceituação de guerra global de Ludendorff e, na $2^{\text {a }}$ Guerra, foi consagrada em definitivo, com a mobilização de tôdas as fôrças vivas das nações em conflito.

Assim é com relação aos economistas e aos pensadores, do vulto de um Padre Bastos de Ávila, quando prevê, com lucidez, a necessidade de reformar a emprêsa, para conservá-la, ou condená-la "a uma forma qualquer de socialismo estatal".

F. Bloch Lainé defende, igualmente, as razões de inovar. "Não se pode - afirma êle - ao mesmo tempo reconhecer uma evolução e imobilizar a emprêsa. Ela está em franca mutação. É êste fenômeno que se trata de favorecer, modificando - que a entrava, sem pretender determinar seu fim. Tal é o desconhecido de tôda reforma, preferivel porém aos inconvenientes do imobilismo.

Justificando as mudanças que se projetam na emprêsa, pelas incoerências que nela se constatam, arrisca-se de ser acusado, por uns de "brincar de aprendiz de feiticeiro", por outros de "afogar o peixe"; fica-se exposto a desagradar simultâneamente aos prudentes e aos partidários de "tudo ou nada". E um perigo bem conhecido dos reformistas".

O que é importante, todavia, é criar a consciência da necessidade de reformar, para que a emprêsa seja um instrumento a serviço do bem comum e, conseqüentemente, da justiça social.

Vários caminhos têm sido tentados, com resultados diversos, decepcionantes uns, promissores outros.

Três grandes correntes de idéias se distinguem. Na primeira o esfôrço se faz em aperfeiçoar as técnicas de relações humanas na emprêsa, visando melhorar, com uma boa política de pessoal, quer 0 ambiente social, quer a eficiência da emprêsa.

A segunda corrente localiza na estrutura da emprêsa o seu defeito, sustentando que nada se poderá melhorar nas relações entre os homens que nela trabalham, enquanto não se remover a causa determinante da deterioração dessas relações, que é a marginalização do trabalhador dos resultados da emprêsa e das decisões de que depende o seu futuro. As medidas de participação nos lucros e na direção das emprêsas públicas ou a co-gestão das emprêsas privadas são as principais reivindicações da corrente estruturalista, que visa a reforma da emprêsa capitalista.

Finalmente, há o movimento dos que pretendem, sobretudo, regulamentar, limitando-o, o comportamento dos dirigentes da 
emprêsa, de sorte a restringir sua liberdade de ação, ou seja, mudando a estrutura monárquica absolutista da emprêsa, por uma estrutura "constitucional", cuja autoridade se exerça segundo regras de jôgo prèviamente acordadas entre a emprêsa e o seu pessoal.

O direito de ampla sindicalização, a negociação coletiva, o direito efetivo de greve, a imunidade dos dirigentes sindicais eleitos livremente, o direito de participar e o de contestar sem correr o risco de demissão sem justa causa são, entre outros, os pleitos mais comuns a essa corrente, que, como salienta Jean de Givry, deseja um "estatuto do trabalhador, que the conceda, em relação ao poder de arbítrio do empregador, garantias que são semelhantes às contidas nas constituiçôes que definem os direitos fundamentais dos cidadãos, frente ao poder público".

Analisando os resultados até aqui obtidos por tôdas essas correntes, $\mathrm{F}$. Bloch Lainé parece um pouco pessimista:

"Os meios postos em prática até o presente, tanto na França quanto em qualquer outra parte, no sentido de fazer coexistirem o direito de participar e a liberdade de contestar não atingiram ainda seus frutos."

"1 - A política das "relações humanas" que está em moda, demonstra que bom número de chefes de emprêsa já tomou consciência da delicadeza dos problemas que nascem de suas relações com o seu pessoal; êles reconhecem implicitamente que os assalariados têm direitos outros além daquele de perceber um salário justo. Mas, isso é ainda insuficiente: não se pode criar uma "consciência de emprêsa" sem tocar na constituição desta.

"2 - As diversas fórmulas de participação nos lucros, encorajadas ou não pelo Estado, não trazem, também, solução completa; não maior que a ilusória transformação do assalariado em acionista, do qual se conhece a ausência de poder real nas sociedades anônimas.

"3 - A fórmula do intróito da Constituição francesa de 1946 , segundo a qual "todo trabalhador participa, por intermédio de seus delegados, da gestão das emprêsas", não é a expressão da realidade. Os delegados de pessoal são intermediários preciosos; mas a função reivindicativa que exercem é reduzida pelo fato de que o empregador não é obrigado a dar prosseguimento às reclamações que lhes são dirigidas.

Os conselhos de emprêsas, de que se esperavam grandes resultados, estão numa tal crise, que os sucessos obtidos no 
campo das obras sociais não são suficientes para mascará-la. Diversas causas podem explicá-la: a hostilidade patronal, confirmada à medida que se transformava o clima existente em 1945 e manifestado, principalmente, pela raridade das reuniões; a parcimônia dos comunicados aos "comitês" e o pequeno interêsse emprestado às suas sugestões; a atitude de certos Sindicatos que utilizaram os "comitês" como instrumentos de luta, a confirmar, assim, a reação dos empresários; enfim, a ausência de formação dos representantes do pessoal, quase sempre mal preparados para examinarem problemas econômicos.

"4 - O sistema alemão de co-gestão que parece a solução mais ousada no campo capitalista, é equívoco, pois que há, necessàriamente, no interior das emprêsas como no interior das nações, governantes e governados. Se os assalariados, enquanto governados, podem aconselhar e controlar, os empregadores, enquanto governantes, não têm vocação nem interêsse de se transformarem, através de seus delegados, em empregadores-governantes.

Não há campo para uma verdadeira associação de gestão, entre uns e outros, senão quanto às atividades anexas. Que todos os governados possam ter acesso ao govêrno, é o princípio mesmo da democracia. A democracia industrial, como a política, não será uma realidade senão quando os assalariados participem correntemente do govêrno da emprêsa, sem contudo traírem suas origens. Entretanto, fiéis que êles sejam aos seus companheiros, não deverão jamais ser impostos à emprêsa através de um mandato imperativo."

Em 1967, a Organização Internacional do Trabalho patrocinou uma reunião em que se discutiu amplamente o sistema de co-determinação das minas de carvão e da indústria siderúrgica da Alemanha Ocidental, bem como o de autogestão das emprêsas iugoslavas.

Concluiu-se que o princípio da participação é mais fàcilmente aceito quando corresponde ao estudo, em comum, das decisões que influem diretamente nas condições de vida e de trabalho dos assalariados. Entretanto, consideráveis obstáculos surgem se se trata da participação dos trabalhadores nas decisões econômicas e financeiras, ou mesmo quando do processo de produção.

Resulta disso a enorme dificuldade de distinguir as decisões que afetam, daquelas que não afetam, os trabalhadores. Estes sustentam que pràticamente qualquer decisão ao nível da emprêsa terá conseqüências para os trabalhadores. Neste ca- 
so, é mais justo e conveniente que o trabalhador participe da decisão desde logo e não, apenas, das decisões decorrentes, acrescentam êles.

Os patrões, em contrapartida, argumentam que será fatal à emprêsa a partilha do poder de decisão e que se deve estabelecer uma clara linha demarcadora das funções de direção e das atribuições do Sindicato, sem o que se compromete a economia de qualquer país.

O patronato alemão bate-se firmemente contra a expansão do regime de co-determinação (Mitbestimmung), ao qual denomina de mito. Para provar que o regime não é vantajoso, pois não tem obtido melhores resultados, com relação às relações industriais e à integração do trabalhador, que o sistema geral aplicado na Alemanha, a Confederação patronal encomendou uma avaliação ao Instituto de Pesquisa Social (EMNID), envolvendo um número igual de trabalhadores empregados nas indústrias básicas, sob os dois diferentes regimes.

Foram ouvidos 2.000 operários, metade dos quais empregados nas indústrias siderúrgicas e minas de carvão, submetidas à co-determinação.

Os resultados foram surpreendentemente decepcionantes para os defensores da co-determinação como instrumento de justiça social e de integração do trabalhador na economia e na sociedade.

A pesquisa provou que os trabalhadores não sujeitos à codeterminação:

- sentem-se mais bem informados pela direção da emprêsa;

- consideram-se mais seguros no seu emprêgo, sofrendo menos demissões sumárias;

- identificam-se melhor com suas emprêsas;

- estão mais satisfeitos com seus salários.

Ora, a fundamentação filosófica de co-determinação é a identificação do capital com o trabalho, a transformação do natural sentimento de competição, em cooperação. Se isso fracassa na prática, o instrumento não é bom, positivamente.

Não é muito diverso o quadro das emprêsas brasileiras em que se adota a participação nos lucros. Por vêzes, em lugar de euforia na ocasião do recebimento da vantagem, o que se nota é frustração, é ressentimento causado pela sensação de injustiça que advém da comparação com outros companheiros mais bem aquinhoados. 
De resto, essas mesmas emprêsas não fugiram, no passado recente, à agitação que dominou o sindicalismo brasileiro, às greves sem justificação, às campanhas salariais exorbitantes.

E melancólico reconhecer que a participação nos lucros, bem como a participação na direção das emprêsas, têm provado muito pouco em favor da tese que nelas identificam os meios práticos para obter-se a aliança entre patrões e empregados, com vistas à implantação da emprêsa comunitária.

Um líder sindical francês, a êste respeito, comentou:

"Não cremos, hoje, mais que no passado, nas virtudes da associação do capital com o trabalho. Ao conceito de associação, opomos o de contrato."

Ao que tudo indica, êste ainda será o caminho a percorrer por longo tempo: o contrato que limita o poder do mais forte, a lei no sentido que Lacordaire Ihe emprestou, a legislação protetora dos trabalhadores, que faz aplicar certas normas em matéria de condições de trabalho e o Sindicato, como instrumento de pressão na dinâmica democrática, a servir de contrapêso em relação às pressões patronais.

Através dêsse jôgo de neutralizações vem se efetuando a transformação da emprêsa ao longo da história do capitalismo; mas só essa transformação lhe garantirá a sobrevivência.

Nota: Pronunciamento do Ministro Júlio de Carvalho Barata, do Tribunal Superior do Trabalho, - posteriormente Ministro do Trabalho e Previdência Social, no Ministério do Presidente Emílio G. Médici, - sôbre o trabalho do Ministro Jarbas Gonçalves Passarinho ora divulgado no presente volume da Revista do Serviço Público:

"O Ministro Jarbas Gonçalves Passarinho oferece, nestas páginas, definição clara de uma filosofia trabalhista, liberta de impregnação fascista, imune ao contágio marxista, inspirada em normas cristãs e democráticas e ajustada à realidade brasileira.

A exportação das idéias implicava um depoimento histórico. Era preciso, primeiro, apreender o fenômeno nacional no campo das relações entre capital e trabalho. A seguir, impunha-se o desmonte dos sofismas, da propaganda e da ação subversiva, que viciaram, durante longo tempo, o ambiente oficlal e obrigaram o povo e as Fôrças Armadas a deflagrar o movimento de março de 1964.

O esfôrço de clarificação e desbastamento foi cumprido, neste trabaiho, com lucidez e coragem, por um estadista môço, dotado de sólida formação militar e de qualidades raras de inteligência, enriquecidas agora pela vivência do problema trabalhista, no exercício do cargo de Ministro de Estado do Trabalho e Previdência Social.

Um estudo do teor e da brevidade do presente era necessário. Muitos tratados se escreveram sôbre direito do trabalho, sôbre sindicalismo e sôbre justiça social. Mas o que nos faltava era uma 
condensação e uma vulgarização das idéias básicas, que devem reger a confecção das leis e o funcionamento das instituições, sempre que o Estado seja chamado a disciplinar o convívio de empregadores e empregados.

O vocabulário do trabalhismo transformou-se, entre nós, numa seara de equívocos. Serviu à demagogia, ao empreguismo, ao jôgo eleitoral. Ả custa de ambigüidades bem urdidas e de generalizações solertes, a política trabalhista corrompeu-se, abrindo o flanco às incursões de dois grupos, opostos pela ideologia e irmanados pela finalidade do assalto ao poder. Comunistas, de um lado, e pelegos, de outro, minaram o sindicato, roubando-lhe a autenticidade e erigindo-o em instrumento de camarilhas, à conta de interêsses divorciados do interêsse coletivo.

O mais profundo da deformaçăo era a presença de ideologias, provocada pela ausência de uma filosofia.

A ideologia é um somatório de teses adrede construídas para justificar uma situação política ou uma conduta personalista.

A filosofia é sempre um sistema racional de princípios altos, expressão de um ideal, adaptado à realidade e à conjuntura. Filosofia genuína, em contraposição ao oportunismo intelectual, próprio das ideologias, é aquela que surge, como imperativo da razão, da análise do objeto para a síntese do pensamento.

Ora, no âmbito da política trabalhista, o objeto é o homem, olhado pelo prisma da verdade, isto é, como ser hibrido e como ser social. Hibrido: matéria e espírito, corpo e alma, cidadão de dois mundos, no dizer de Otto Wilmann. Social: não apenas ser, mas com-ser ou ser-com, não só Desein mas Mitsein, no dizer de Heidegger, e, como tal, fadado à coexistência no seio de uma comunidade.

O primeiro predicado, que nega o homem como coisa e afirma o homem como pessoa, destrói o postulado materialista e elimina a possibilidade de uma política trabalhista orientada pelo marxismo.

O segundo predicado nos obriga a uma concepção de solidariedade dos indivíduos, de interaçăo das pessoas, de equitativa distribuição de bens e de encargos em vista de um fim supremo - 0 bem comum.

E assim e por isso que ao lema da luta de classes, base da ação marxista, se opõe o lema da harmonia entre o capital e 0 trabalho, base da ação cristã.

A luz dêstes princípios, desdobram-se as considerações do Ministro Jarbas Gonçalves Passarinho sôbre os conceitos de trabaIho, propriedade, salário, organização sindical.

Empresários e operários lucrarão muito com a leitura desta cartilha trabalhista, que aponta os direitos e os deveres de cada um, justificando-os sempre com a única fôrça invencível - a fôrça das idéias retas e justas." 